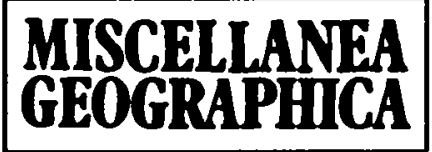

WARSZAWA 1992 Vol. 5

Dobiesław Jędrzejczyk

\title{
BENON JANOWSKI AS THE PIONEER OF APPLICATION OF GRAVITATION MODELS (PATTERNS) IN THE GEOGRAPHICO-ECONOMIC RESEARCH
}

The positivist doctrine flourishing at the end of the 19th and beginning of the 20th century has exerted a decis ive influence on the development of the modern geographico-economic thought. Its foundation was the belief that the identical principles can actuate the process of getting to know nature as well as human and social reality. These principles were to be supplied by the classic mechanics because among the empirical disciplines it has produced the most exact ways of description; moreover, among its explanations are included phenomena and peculiarities most universal in nature, that is of the kind without which no other ones appear.

The pioneer of positivism in the Polish economic geography is Benon Janowski who at the begining of the century had already produced a concise treatise on the applications of mechanistic principles and rules to the spatialeconomic investigations (Janowski 1908). His work was published in the relatively small number of copies by the "Society for Support for the Polish Science" that had played a very important role in the development of the Polish science at the turn of the 19 th and 20 th centuries.

Benon Janowski's idea was completely forgotten for nearly 60 years. The first researcher who turned his attention to Janowski's work was W. Krzyżanowski (1927) in his essay on the location of industry. For W. Krzyżanowski, however, B. Janowski's concept was only an interesting expansion of J. H. von Thünen's thought. This concept was brought back to the literature of the subject only by $\mathrm{Z}$. Chojnicki (1966) who regarded B. Janowski as co-author (besides H.C. Carey and E.G. Ravenstein) of the "demand and supply rule" formulated in the form of the rule of gravitation.

However, the work of B. Janowski by far outgrows an attempt to formulate a rule of demand and supply for the socio-economic formations. The principal thought of Benon Janowski's concept postulates an application of the energetic rules to the analysis and explanation of the social phenomena in general, and spatio-economic in particular (Jedrzejczyk 1987). In this case, social energy is an active element. In all spatio-economic structures, including those concerning 
hand-made products, it is not only a quantity of kinetic energy used by the producer that is unknown but also a quantity of potential energy to be used by the consumer. It is so because in such structures the idea of value corresponds exactly to the energy, according to the then theory of the Swiss school.

The recognition of the useful energy as an equivalent of the value causes that exchange ability of some goods may be evaluated in terms of quantity of work that ought to be done to produce these goods. A measurement of the value of goods would be an easy matter if equivalents of the value of work or energy useful in the various socio-ecenomic structures were known.

Since it is impossible to effect this measurement in practice, as value-energy can be measured only in terms of work, Benon Janowski suggests to apply the only though - as he frankly admits - imporfect measure, namely money. Because the value expressed in money is a price, the price can be recognized as an adequate measure of energy in the aspario-economic formations. Thus, the monetary measures system in the socio-economic formations is an equivalent of the system of gravitational measures (weight) in mechanical structures.

According to Janowski, if the average prices (daily, monthly, yearly) of any object were marked in various points in space and linked by lines, the effect would be the lines of average work which in the given period of time (day, month, year) is to be done to take posession of the unit of this produce. In other words, Janowski assumes that the value of price in the spatio-economic structure corresponds to the value of potential in physics. Thus the lines of equal prices are levels of the equal potential of the masses in the gravitational structure or electric charge in the electric field.

The zero value of goods that man can get at no cost or get rid of at no loss corresponds to the zero potential in the socio-economic structures. In this interpretation of zero value there are "free" goods, i.e. natural goods such as water, air, sunlight and all those products which entirely loose their value temporarily. Thus the difference in prices corresponds to the difference in physical potential. Like the material substances fall from the upper levels to the lower ones, and electricity flows from the higher potential to the lower, the more valuable goods argues B. Janowski - effectively replace less valuable goods. Assuming as the same the value of objects, those which cost less will win in the market. In this case the difference in prices corresponds to the difference in potentials.

In the light of this interpretation it is clear that an exchange can proceed only from the places where a merchandise is cheaper to the places where it is more expensive. But the force of this exchange depends, of course, on the difference of prices and distance between places displaying this difference. And a difference in prices corresponds, in conformity with the rules of mechanics, to the difference in work, the quality of goods being the same.

This article includes five maps showing the prices of wheat in the AustrianHungarian monarchy and separately in Galicia, prices of meat in Germany and finally prices of beef and maize in Hungary (Fig. 1). They have been made on various scales using isolinear method, and their contents is presented by - as 


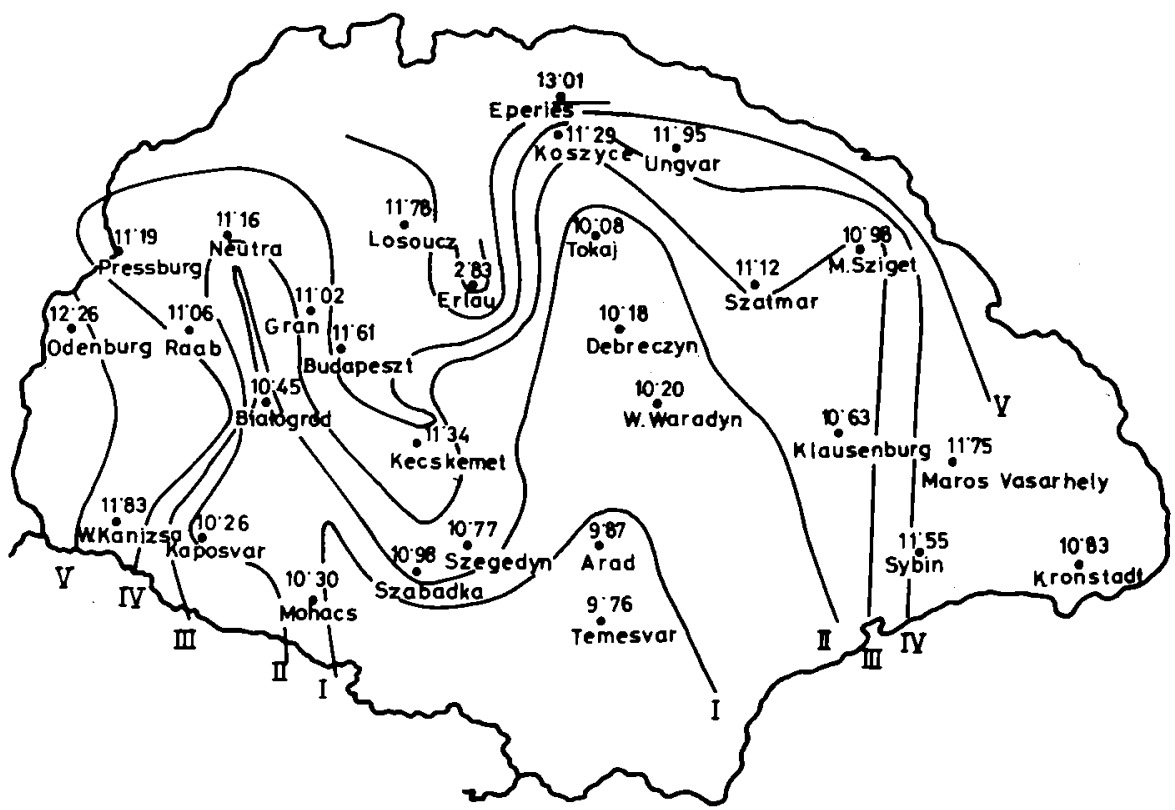

Fig. 1 The lines of maize prices in Hungary in the year 1902 (in crowns per $100 \mathrm{~kg}$ ).

Janowski used to say - "lines of prices". The isolinear technique has - in his opinion - this valuable peculiarity that shows - even on the basis of the relatively narrow class of statistical data - their main course dependent on the conditions of production. Besides, the purpose of the construction of this map is, as Janowski holds, not so much the exact definition of what part is paid for the unit of goods in the given locality "(...) a visual understanding of the general dynamic relations which characterize all spatio-economic arrangements".

Benon Janowski also introduced an idea of the unit of profit defined by the formula extracted by him:

$$
\text { unit of profit }=\frac{\text { unit of work (in crowns }}{\text { unit of merchandise (in tona) } \text {. Unit of distance }(\mathrm{km})}
$$

The interpretation of the above-mentioned maps is interesting. According to Janowski, greater profit causes greater movement on the given trade route that lasts until the difference in prices grows smaller, and the profits are reduced to the minimum. If on a given route there were no railroad line or road connection in general, which is usually the case when differences in prices are considerable the price lines would, in B. Janowski's opinion, allow us for example, to determine the profitability of the planned transport line. For it is clear that the railways will be more profitable in those areas where distances among the localities are small than in places where the relatively small differences in prices are noted. So the map of price lines can be, as B. Janowski says, a basic tool in planning the 
course of railroad lines which, in effect, constitute a foundation of the spatioeconomic structures.

Benon Janowski's work is the first in the Polish literature, and probably the first in the world literature, attempt at presentation of the cartographic socioeconomic reality in the category of the so-called social physics. This direction, which is very fertile not only in the economic geography but also in sociology and economy, takes a stand of commensurability of the socio-economic theories and the theory of physics. It means that the models (patterns) of classical physics, for example gravitation models (patterns), are consistent with the structure of the socio-economic reality in the epistemological as well as ontological scheme. However, Janowski goes farther than his predecessors (for example, Carey or Ravenstein) because considering his concept of the spatio-economic structures in categories of the Newton's gravitation theory, he accepts the categories of value and price as the fundamental ideas which depict the sphere of reality. That is why he presented the innovative cartographic picture of the economic potential of the particular region and defined a force of exchange among its component parts.

Benon Janowski's work undoubtedly belongs to the group of the most outstanding achievements of the European economic geography in the 20th century. Even today it can be an inspiration for further research on the methods of analysis of the spatial structures.

\section{REFERENCES}

Ch ojn i cki Z., 1966 "Zastosowanie modelu grawitacji i potencjału w badaniach przestrzennoekonomicznych" (Application of the gravitation and potential models in the spatialeconomic research), Studia, Vol. XIV, Committee for Spatial Management of the CountryWarszawa.

Ja n ow ski B., 1908, "O odległościach jako czynniku rozwoju kultury" (Distances as factors of cultural development), Archiwum Naukowe, Section 1, Vol. 4.

Jędrzejczyk D., 1987, "Mapy potencjału gospodarczego oraz sily wymiany handlowej w ujęciu Benona Janowskiego (Maps of the economic potential and forces of trade exchange in Benon Janowski's approach), Polski Przeglad Karlograficzny Vol. 19, No. 4, pp. 175 178.

Krzy żan ow ski W., 1927, Lokalizacjaprodukcji (Location of production), Polska Akademia Umiejętności, Kraków. 